\title{
Marina Balažev
}

\section{Hrvatski standardni jezik i narativne prakse među Hrvatima u Vojvodini}

\author{
Prethodno priopćenje \\ Preliminary communication \\ UDK 159.923.2:811.163.42'26(497.113)
}

Teorijsko polazište rada su osnovne postavke kognitivne lingvistike i suvremena teorija identiteta koja ide u smjeru dekonstruiranja esencijalističkog pristupa pojmu te idenititet promatra kao narativ. Rad donosi pogled na identitet kao konstrukt u formi narativa pri čemu su neki segmenti identiteta (npr. nacionalni identitet) rezultat pounutrenja narativa koje proizvodi i održava društvo odnosne neke njegove instance. Uloga jezika u konstrukciji narativa je dvostruka i ovaj rad istražuje ulogu jezika u konstrukciji nacionalnog identiteta kod pripadnika hrvatske nacionalne manjine u Srbiji. Također, rad donosi neke osnovne narative koji se proizvode od strane političkih predstavnika hrvatske manjinske zajednice.

Ključne riječi: identitet, narativ, konstrukcija identiteta, jezik i identitet, nacionali identitet, Hrvati u Srbiji

\section{Uvod}

$\mathrm{U}$ radu ćemo identitet, prema suvremenoj teoriji identiteta (McAdams 2006), promatrati kao priču odnosno narativ koji nastaje kao odgovor na pitanje Tko sam ja?. Ta priča velikim dijelom izrasta iz iskustva. $\mathrm{S}$ druge strane nacionalni je identitet, također konstrukt, narativ, koji dijelom osobnoga identiteta postaje internalizacijom narativâ o nacionalnosti koje stvara društvo. 
U prvom poglavlju objasnit ćemo povezanost osobnog identiteta i iskustva, kao i načine konstrukcije nacionalnog identiteta. Dalje ćemo prikazati odnos sadržaja mitske povijesti ${ }^{1}$ i narativâ kojima se (pr)opisuje što nacionalni identitet jest $u$ danom vremenu i prostoru i to oprimjeriti rezultatima istraživanja slučaja Hrvata iz Vojvodine. U trećem ćemo poglavlju prikazati odnos jezika i nacionalnog identiteta, na već spomenutom primjeru, i ukazati na nemogućnost stabiliziranja hrvatskoga standarda kao oznake identiteta.

U poglavlju koje slijedi donosimo teorijske postavke koje objašnjavaju konstrukciju osobnoga odnosno nacionalnog identiteta. Nakon toga osvrnut ćemo se na način internalizacije narativa i objasniti ga biološkom uvjetovanošću konceptualizacije kroz formu priče.

\section{Identitet}

Prema Kahnemanu svijet doživljavamo kroz dva Ja: Ja koje doživljava i Ja koje se sjeća - odnosno proživljeno tumači, valorizira, daje mu značenje, pamti dijelove proživljenoga i ugrađuje ih u identitet. Tako je identitet priča nastala iz iskustva koje je proživjelo Ja koje doživljava, a koje je prepričano, selektirano i upamćeno od Ja koje se sjeća (Kahneman 2013). Terminologijom kognitivne lingvistike možemo reći da konstrukcija identiteta ovisi i o offline i o online procesuiranju (Barsalou 2003) te da se identitet pohranjuje u pamćenju, neraskidivo je vezan uz jezik i rezultat je različitih značenja koja su postala dijelom vlastitoga narativa. Identitet je konstrukt koji se u skladu s novim iskustvima stalno iznova gradi i (pre)priča(va). Ta je priča višeslojna, postoji u različitim verzijama, često se ne poklapa s pričom koju drugi imaju o nama. Dijelom identiteta, osim proživljenog i protumačenog iskustva, postaju i poruke o nama koje nam upućuje značajni Drugi kao i narativi koje proizvodi društvo i koje internaliziramo.

\section{1. Identificiranje - internaliziranje narativa}

Za pitanje nacionalnoga identiteta sam način postanka nacije nije ključan jer se nacionalni identitet konstruira neprestano $u$ danom trenutku na određenom prostoru i u stalnoj je mijeni ovisno o promjenama konteksta. Nacionalni identitet se konstruira u obliku narativâ koji se legitimiziraju drugim narativima - sadržajima mitske povijesti - i institucijama moći putem kojih dolazi

1 „Mythico-history“ termin je koji uvodi Malkki, a predstavlja odabir priča/povijesnih događaja (svejedno stvarnih ili izmišljenih), a koje su značajne za uspostavu značenja te kozmološkog i moralnog poretka unutar skupine koja se s pričama identificira. 
do individualizacije odnosno pounutrenja. Na taj način nacija proizvodi svoje subjekte i samu sebe.

Zašto je to moguće i u čemu je „moć“ narativa? Narativi, odnosno pričanje priča su osnovni instrumenti mišljenja o kojima ovise i racionalni kapaciteti i taj je literarni kapacitet mozga neodvojiv od ljudske kognicije uopće. (Turner 1996: 5). Osim što poimamo svijet kroz strukturu priče, zahvaljujući neuralnom povezivanju možemo razumjeti narative i uloge u njima, no to isto neuralno povezivanje stvara i emotivno iskustvo što znači da narativi s kojima se identificiramo izazivaju snažnu emocionalnu reakciju. (Lakoff 2009: 28). Drugim riječima, biološki smo uvjetovani da prepoznajemo strukturu priče i da se s nekim pričama identificiramo. To je u osnovi identificiranja s nizom narativa pa i s narativima o nacionalnosti. Osim toga, ono $s$ čime se identificiramo postaje fizičkim dijelom mozga (Lakoff 2009: 59), a zahvaljujući zrcalnim neuronima svaki put kad se susretnemo s narativom s kojim smo se identificirali (u medijima, u životima drugih, u udžbenicima itd.) taj se narativ još više „urezuje“ u naš mozak te se javlja i osjećaj zajedništva i povezanosti.

\section{2. Mehanizmi i sadržaji konstrukcije nacionalnog identiteta}

Vidjeli smo da je osobni identitet velikim dijelom rezultat narativiziranog iskustva i interanliziranih narativa. No, ne identificiramo se sa svim narativima nego s onima koji su bliži iskustvu, upravo se stoga narativi o naciji oslanjaju (i izrastaju) iz svakodnevnih praksi. Mnogi se od njih legitimiziraju kao sadržaji mitske povijesti.

Život na zajedničkom prostoru i interakcija s drugima koji obitavaju na istom prostoru rezultiraju određenim zajedničkim svakodnevnim praksama od kojih neke mogu postati obilježjem određene skupine, koje ga npr. razlikuje od neke druge prostorno bliske skupine, i oznakom identiteta. Za razliku od malih skupina, nacionalna država na velikom prostoru povezuje cijeli niz različitih lokalnih skupina (Anderson 1991) čije se svakodnevne prakse razlikuju u većoj ili manjoj mjeri. Nacija je „nadlokalana“ i „nadskupna“, a da bi se u toj raznolikosti postigla kohezija u vidu nacionalnoga identiteta potrebno je "vezivno tkivo“, a to su u suvremenim nacionalnim državama sadržaji mitske povijesti i narativi koji (p)opisuju suvremene značajke nacionalnoga identiteta.

Osnovnu strukturu složenog narativa o nacionalnosti koji povezuje priče mitske povijesti sa suvremenim narativima mogli bismo prikazati kao u (1) 
(1)

MI SMO X JER SMO DOŠLI/POSTOJIMO

(sadržaji mitske povijesti koji grade privid trajanja u vremenu)

\section{A NAŠE SU SPECIFIČNOSTI}

(narativi koji opisuju što u danom trenutku na određenom prostoru znači biti Xom, niz promjenjivih elemenata koje se pretvaraju u obilježja nacionalnog identiteta među kojima su često jezik, pismo, vjera, neki segmenti kulture itd.)

\section{ZATO SMO DRUGAČIJI OD}

(značajni Drugi danog trenutka jer se (auto)identifikacija, pa tako i nacionalna (auto)identifikacija događa uvijek u odnosu na Drugog).

Nacionalni je identitet skup narativa ispričanih iz pozicije moći u određenom presjeku vremena i prostora, a Čapo (2010: 249) ga opisuje kao situacijski jer ga ne možemo promatrati izvan situacije u kojoj se stvara; relacijski jer kao predodžba o sebi uvijek ovisi o nekom važnom Drugom danoga trenutka, interaktivan jer konstruira istosti prema unutra i različitosti prema van te refleksivan jer je slika koju konstruiramo o sebi uvijek odraz toga Drugog te je ili oprečna od njega ako se želimo udaljiti ili pak sukladna ako mu se želimo približiti. Identiteti su političko i ideološko pitanje, stoga dominantne ideologije nekog društvenopovijesnog trenutka određuju dominantne naracije o identitetu (Čapo 2012:249-50).

Da zaključimo: kada govori o uspostavi značenja kognitivna se lingvistika temelji na teoriji iskustvenog relativizma prema kojemu ne postoji objektivni svijet nego naš um i jezik, a znanje primamo uvijek kroz čula pa ono nije objektivno nego je rezultat kulture, komunikacijskog čina i čovjekovih spoznajnih sposobnosti (Stanojević 2013:24). Tako se i narativno-socijalni-konstruktivizam temelji na postavkama da ne postoje suštinske istine jer su stvarnosti socijalno konstruirane i to pomoću jezika te se organiziraju i održavaju narativima odnosno da ljudi zajedno konstruiraju stvarnosti dok ih žive. (Freedman-Kombs 2009: 71-3). Narativi kojima konstruiramo stvarnost, a koji nose poruku nacionalnoga, najčešće se grade oko neke svakodnevne prakse koja se izdvoji i dobiva oznaku nacionalnog. Društveni narativi oblikuju i naše individualne narative (identitete) jer ljudi svoje vlastite narative često usklađuju s narativima kulture u kojoj su rođeni često internalizirajući „dominantne narative“ (White 1991, prema Freedman 2009: 92). Identificirajući se s nečim mi u stvari prihvaćamo društveno konstruirano značenje koje se može razlikovati od našeg 
početnog značenja, a biologija mozga omogućuje inaternalizaciju društvenih narativa.

\section{Sadržaji mitske povijesti i hrvatski manjinski narativi u Vojvodini}

Kada govorimo o položaju manjine ${ }^{2}$, važno je uočiti višestrukosti poruka kojima su izložene: s jedne strane su „većinski“ narativi koji manjinu mogu priznati, ne priznati, biti asimilacijski, više ili manje poklapati se s narativima koje manjina ima sama o sebi itd., a s druge strane su „manjinski“ narativi - oni koji se upućuju s pozicije moći manjinskih institucija. Osim toga, sadržaji se mitske povijesti, posebice kada su u pitanju skupine koje su prošle kroz sukobe, mogu vrlo razlikovati. Ti se sadržaji ne prenose samo kroz udžbenike povijesti nego obuhvaćaju sve ono što se uobičajeno smatra „kulturnim“ nasljeđem, predajom, običajima itd. i ključni su za konstrukciju značenja odnosno definiranja kozmološkog i moralnog poretka u društvu. Osim toga, određuju skupinama mjesto u društvenom poretku.

Kada su u pitanju Hrvati u Vojvodini, vidjet ćemo kako su izloženi suprotnim porukama iz istog izvora te kako se sadržaji mitske povijesti (prije svega oni u udžbenicima povijesti koji definiraju 20. stoljeće i rat 90-ih, glazbenoga, likovne kulture, zemljopisa) radikalno razlikuju: srpski ${ }^{3}$ udžbenici postojanje Hrvata na teritoriju Srbije uglavnom i ne spominju, a događaje 20. stoljeća interpretiraju na način koji je u potpunoj suprotnosti sa sadržajima koji su u hrvatskim udžbenicima. No buduči da u Vojvodini postoji i manjinska nastava na hrvatskom jeziku, očekivali bismo da su sadržaji usklađeni s hrvatskim udžbenicima te da olakšavaju identifikaciju s hrvatskim nacionalnim identitetom, ali praksa pokazuje drugačije.

2 Napominjemo da nema općeprihvaćenog koncepta manjina - katkada se pod tim pojmom podrazumijevaju imigrantske zajednice, katkada skupine koje dulje vremena žive na nekom području; kada su u pitanju Hrvati u Vojvodini riječ je o stanovništvu koje je prostor Vojvodine i neke dijelove Srbije naselilo prije konstituiranja hrvatske nacije u 19. stoljeću. Europska komisija za demokraciju putem prava donijela je 1990. godine radnu definiciju manjine koju bismo mogli parafrazirati i reći da je manjina skupina brojno manja u odnosu na ostatak populacije te da može biti različitih kulturnih i/ili religijski i/ili jezičnih značajka.

${ }^{3}$ Pridjev "srpski" odnosno "hrvatski" ovdje upotrebljavamo kao metonimiju za udžbenike kojima se služi u nastavi na srpskom jeziku u Srbiji odnosno udžbenike kojima se služi u nastavi u Hrvatskoj. 


\subsection{Mitska povijest}

Hrvati su u Vojvodini status manjine dobili 2002. godine kada je donesen Zakon o zaštiti prava i sloboda nacionalnih manjina koji je omogućio formiranje tijela manjinskih samouprava - Nacionalnih vijeća nacionalnih manjina. Tada osnovano Hrvatsko nacionalno vijeće (HNV), koje se financira iz budžeta Republike Srbije, unutar državnoga aparata nema velikog utjecaja „prema gore“ (ne participira značajnije u vlasti), no kada je u pitanju djelovanje „prema dolje“, odnosno prema pripadnicima manjine koju predstavlja, područje djelovanja mu je vrlo široko što se, prije svega, ogleda u velikim ovlastima u planiranju cjelokupne manjinske politike, posebice u pitanjima jezika, obrazovanja, kulture, informiranja. ${ }^{4}$

Jedno je od glavnih polja djelovanja HNV-a nastava na hrvatskome jeziku (koja traje više od desetljeća), a za koju su tek 2014. osigurali udžbenike. Udžbenike je znatnim dijelom financirala Republika Hrvatska preko Ureda za Hrvate izvan $\mathrm{RH}$, a bili su više godina predmetom sukoba jer je, prema riječima predstavnika HNV-a, Srbija odbijala platiti tiskanje udžbenika te time izravno kršila prava manjine (za to su se vrijeme u nastavi koristili udžbenici uvezeni iz Hrvatske).

Za manjinsku nastavu zakon propisuje 30 \% vlastitog nacionalnog sadržaja u udžbenicima iz glazbenoga, povijesti, zemljopisa i likovne kulture (a to je velikim dijelom upravo ona vrsta sadržaja koju nazivamo mitskom poviješću). To je i odraz suvremenih društvenih praksi koje za razliku od konstruktivističkog odražavaju esencijalističko poimanje identiteta koje se temelji na pretpostavci kako kolektivni identitet posjeduje svojevrsnu „bit“ ili „esenciju“ koja se može

${ }^{4}$ Za detaljan prikaz svih ovlasti koja imaju nacionalna vijeća vidi:

a) Nadležnosti nacionalnih saveta nacionalnih manjina, priručnik za nacionalne savete nacionalnih manjina u izdanju OEBS-a (Organizacije za evropsku bezbednost i saradnju Misija u Srbiji), Ambasada Savezne Republike Nemačke Beograd, Ministarstvo za ljudska i manjinska prava državnu upravu i lokalnu samoupravu Uprava za ljudska i manjinska prava Republike Srbije.

b) Zakon o nacionalnim savetima nacionalnih manjina („SI. glasnik RS“, br. 72/2009, 20/2014 - odluka US i 55/2014)

c) izmjena toga zakona iz 2014. Zakon o izmenama i dopunama zakona o nacionalnim savetima nacionalnih manjina)

d) Stručni komentar - komentar zakona o izmenama i dopunama zakona o nacionalnim savetima nacionalnih manjina Sl. glasnik RS, br. 55/2014 Izmenjene i dopunjene odredbe Zakona koje se odnose na statusna pitanja, izbore i konstitutisanje nacionalnog saveta. 
intuitivno spoznati, a potom i opisati. Takav model identiteta Čapo (2012.) još naziva „inventarnim“ jer (p)opisuju što nacija jest (Čapo 2012: 247).

No suprotno zakonu udžbenici koje je HNV pripremio za hrvatsku nastavu, a koji su u uporabi od školske 2014./2015. godine predstavljaju doslovni prijevod srpskih udžbenika u kojima se postojanje Hrvata uopće ne spominje, čak ni u poglavljima u kojem se poučava o manjinama. ${ }^{5}$ Time se učenicima koji upišu hrvatske razrede (i roditeljima koji očekuju mogućnost identifikacije s hrvatskim narodom kojemu smatraju da pripadaju) nude sadržaji mitske povijesti većinskoga, srpskog naroda te se potiče asimilacija ili u najboljem slučaju stvara znatna konfuzija.

\subsection{Hrvati u Vojvodini i manjinski narativi}

Kako su upravo institucije one koje konstruiraju i distribuiraju narative ili kako kaže Bara „svojim kategorizirajuće-klasificirajućim selekcijskim mehanizmima spajaju motive djelovanja i očekivanja te kroz tipizirano ponašanje aktera u ulogama grade društvene strukture“ (Bara 2012: 74) osvrnut ćemo se na narative koji se tiču identiteta, a koje HNV, kao ključna manjinska institucija, nudi hrvatskoj manjini u Vojvodini.

Za korpus tekstova poslužila nam je Hrvatska riječ kao jedini značajniji manjinski tjednik čija je osnivačka prava 2004. godine Skupština AP Vojvodine prenijela na Hrvatsko nacionalno vijeće. Taj tjednik uvelike prenosi sliku svijeta kakvu stvaraju službeni predstavnici hrvatske manjine. Analizirali smo tekstove novijeg datuma i to, prije svega, one koji govore o položaju manjine te citiraju predsjednika HNV-a te ravnatelj Zavoda za kulturu vojvođanskih Hrvata koji je odnedavno i predsjednik stranke Demokratskog saveza Hrvata Vojvodine. Primjeri koje u radu radi ilustracije navodimo iz tekstova su Hrabro ostvarujte svoja prava (iz izdanja 19. 12. 2014.) ${ }^{6}$, Išli smo na razgovore gdje smo bili zvani (iz izdanja 5. 2. 2016.)

Dominantni narativ koji se stalno reproducira jest narativ žrtve. Taj je narativ ugrađen, prije svega, u institucionalni okvir, što se vidi iz naziva zakona: Zakon o_zaštiti manjina - čime je manjina apriori nešto što je ugroženo (od nečega). Takva uloga, Žrtve, implicira pasivnost, a upravo je to stav koji

\footnotetext{
${ }^{5}$ Vidi: Glazbena kultura 8, udžbenik glazbene kulture za osmi razred osnovne škole, autori: Miroslava Petrov i Dragana Grujić, na hrvatski ga je preveo Goran Ružić, BIGZ, Beograd 2014.

${ }^{6}$ Sve tekstove moguće je naći i u arhivi na http://www.hrvatskarijec.rs/arhiva/
} 
predstavnici manjine dodatno potenciraju zauzimajući poziciju „onoga koji zna najbolje“,odnosno Spasioca koji „će inzistirati“, „tražiti“, „zatražiti“, „boriti se“ itd. Pri tomu se narativ Žrtve produbljuje naglašavanjem „prava koja nisu ostvarena“ uz učestalu uporabu glagola „mora“, „treba“, „dužna je“, „nije ispoštovala“ itd. kojima se referira na državu.

Žrtva-Progonilac-Spasilac uloge su u dramskome trokutu, konceptu kojeg je 1968. definirao Steven Karpman kako bi analizirao dinamiku međuljudskih odnosa. Taj je koncept jedan od ključnih koncepata transakcijske analize pomoću kojega prepoznajemo pozicije koje nisu zdrave (a ni jedna od navedenih uloga dramskog trokuta to nije) te nas uči kako izbjeći igranje pojedinih uloga, odnosno kako istupiti iz trokuta ako smo se zatekli u njemu. (Karpman 2015).

Stanje pasivnosti Žrtve (i onemogućavanje aktivnosti) učvršćuje se uopćavanjem i izostavljanjem detalja. U uporabi su učestale fraze poput „prava koja nisu ostvarena“ ili „,zakoni koji su na štetu manjini“, „,teško stanje manjinskih prava" - vrlo općenite sintagme čije značenje nije jasno definirano i koje kao takve stvaraju nevidljivu prijetnju protiv koje se ne može poduzeti ništa. Izuzimanjem činjenica onemogućuje se sagledavanje situacije, a strah koji se na taj način stvara postaje apstraktniji i time jači.

(...) Hrvati u Novom Sadu nisu na pozitivan način prihvaćeni (...)

(...) sadašnja vlast ne nudi sigurnosni okvir (...)

(...) Naravno, istaknut ćemo kako je najteže stanje glede manjinskih prava u obrazovanju. To nije isključivo mišljenje hrvatske manjinske zajednice nego gotovo sva manjinska vijeća smatraju da Ministarstvo prosvjete ili zanemaruje, ili vodi antimanjinsku politiku to je sada sasvim drugo pitanje, ali učinak je jednak, dakle veoma otežano ostvarivanje prava na obrazovanje.

Drugi se oblik konstruiranja narativa žrtve ogleda u potenciranju straha i oživljavanja 90-ih kao u primjeru:

(...) Njena izjava je negativno prokomentirana od prisutnih, navodeći da bi to bilo glasanje za "četnike", kao i za nekoga tko je ubijao hrvatski narod, na što je predsjednik DSHV-a odgovorio: "U načelu se slažem s gospođom da trebamo surađivati i s crnim đavolom kako bismo ostvarili naš interes, jer nije važno na koja vrata uđete nego da izađete na vrata koja vi hoćete(...) $)^{7}$

7 Činjenica jest da je pojedini predstavnici sadašnje Vlade Srbije imaju diskutabilnu prošlost. No ono što se uporno zanemaruje jest da, iako su na sceni neki akteri iz 90-ih ovo više nisu devedesete, situacija više nije ista. To samo po sebi ne znači ni dobro ni 
Vraćanje u okvir 90-ih na nekim je mjestima puno suptilnije, ali i dalje prisutno. Članak koji govori o osnivanju Ureda za ljudska i manjinska prava i o posjeti novog direktora toga ureda HNV-u:

(...) ono što mislim da je pozitivna stvar u svemu ovome jest da novopostavljeni direktor Ureda za ljudska i manjinska prava ima iskustva u domeni ljudskih prava. To se ne odnosi samo na njegovu aktivnost vezano uz suradnju sa Sudom za ratne zločine počinjene na području bivše Jugoslavije, nego prije svega on ima i iskustva u nevladinom sektoru. Tako da su naša očekivanja ipak nešto viša u odnosu na prvo vrijeme kada je formirana Vlada i (...)

Druga je vrsta narativa ona kojom se (pr)opisuje što znači biti Hrvatom u Vojvodini danas, dakle narativi koji (pr)opisuju značajke nacionalnog identiteta: (...) čestitajući praznik svim pripadnicima hrvatske zajednice u Republici Srbiji i pozivajući da "osobnim primjerom hrabro ostvarujete manjinska prava koja nam pripadaju, da sudjelujete $u$ radu kulturnih udruga $i$ posjećujete njihove manifestacije, da redovito čitate hrvatski tisak i gledate TV dnevnik na hrvatskom, da upisujete djecu na nastavu na hrvatskom, koristite svoje pravo na službenu uporabu hrvatskog jezika i latiničnog pisma u svim prigodama, jer ćemo samo na taj način pokazati da cijenimo sebe, a bez toga drugi nas neće uvažavati«, kazao je predsjednik HNV.

Takav popis praksi s kojima bi se trebalo identificirati i koje bi trebalo živjeti da bi se bilo Hrvatom vrlo je uzak i isključujući. A priori odbacuje sve alternativne narative poput onih koje žive pojedinci koji ne prate folklorne sadržaje i ne čitaju manjinski tisak, nego žive svoje priče u kojima se identificiraju s nekim drugim značajkama koje prepoznaju kao „hrvatske“.

\section{Jezik i identitet}

Ideja o jeziku kao izrazu identiteta duboko je ukorijenjena (vidi npr. Peti Stantić 2013: 29), no o jeziku kao izrazu nacionalnoga identiteta ne možemo govoriti prije konstruiranja nacija. Anderson objašnjava kako od različitih vernakulara u procesu standardizacije jedan postaje standardnim jezikom i to zahvaljujući razvoju tiska koji je stvorio unificirano polje komunikacije i razmjene koje je bilo ispod latinskog (dostupno širokim masama), ali i iznad govornih vernakulara, što je dovelo do pojačane komunikacije među govornicima te omogućilo da se počnu prepoznavati kao dio tog „jezičnog polja“ (Anderson

loše ali stalni strah i anksioznost koji se izazivaju narativima dovode do toga da ljudi zbog nemogućnosti jasne prosudbe donose odluke koje su im na štetu. 
1991). U određenim povijesnim trenucima kada skupina koja je u poziciji moći pokrene procese homogenizacije, rezultat iste (a kasnije i sredstvo) standardni je jezik. Trenutak uspostave veze između jezične i etničke zajednice podudara se $s$ politizacijom vernakulara i njegova povezivanja s određenim teritorijem (Škiljan 2002). Nakon toga se u sklopu jezičnoga planiranja definiraju: status odnosno pravni okvir u sklopu kojeg jezik postaje službenim, korpus promjene unutar jezika koje se planiraju u lingvističkim institucijama ili unutar društvenih elita koje pružaju jezični uzor te usvajanje odnosno poučavanje jezika (Wright 2010).

\section{1. Hrvatski jezik u Vojvodini}

I u slučaju Hrvatske jezik se smatra jednom od ključnih sastavnica nacionalnog identiteta ${ }^{8}$, a nakon osamostaljenja bilo je važno utvrditi status hrvatskoga jezika - standardizirati ga te ga, prije svega, učiniti jasno različitim od srpskoga (Peti-Stantić 2013). Po uzoru na Hrvatsku, predstavnici hrvatske manjine u Vojvodini odabrali su jezik kao jedan od ključnih označitelja identiteta, što je vidljivo iz nastojanja da hrvatski jezik postane jedan od službenih na teritoriju Vojvodine (u mjestima u kojima se veći dio građana izjasnio da pripada hrvatskoj naciji), uvođenjem nastave na hrvatskom jeziku i medija na hrvatskom (npr. tjednik Hrvatska riječ) te nekoliko sati tjedno radijskog i televizijskog programa. Hrvatski je kao službeni jezik u uporabi na cijelom teritoriju grada Subotice, a od 2009. i jedan je od službenih jezika u Vovjodini (Vuković 2010: 79). No, za razliku od situacije u Hrvatskoj gdje je hrvatski standardni jezik podvrgnut procesu restandardizacije kao obliku jezičnog planiranja (Peti-Stantić 2009: 71), u Vojvodini se jezično planiranje događalo samo na polju statusa dok je pitanje korpusa preuzeto po uzoru na stanje u Hrvatskoj. U Vojvodini u središte pozornosti zato dospijeva planiranje statusa, planiranje usvajanja i uporabe te planiranje prestiža i diskursa (Vuković 2010).

Da bismo prikazali jezičnu situaciju poslužit ćemo se terminima koje uvodi Czerwinski, a koji procese upravljanja jezikom promatra kroz makrorazinu koja se ostvaruje u i po zakonu te mikrorazinu koju definira kao „diskursnu agitaciju u cilju promjena jezika." (Czerwiński 2009: 14). lako se procesi koje opisuje u planiranju jezične politike odnose prije svega na stabilizaciju i naturalizaciju norme (Czerwiński 2009: 14), mi ćemo se njima poslužiti da bismo prikazali situaciju u Vojvodini pri čemu naglašavamo da se norma stabilizira u Hrvatskoj $i$ kao takva se „uvozi“, dok se u Vojvodini rješava pitanje statusa.

\footnotetext{
8 To je čest slučaj u europskim državama, a za više primjera vidi: Czerwiński 2009: 17.
} 
(2)

\begin{tabular}{l|l}
$\begin{array}{l}\text { MAKRORAZINA } \\
\text { Jezična politika de iure }\end{array}$ & $\begin{array}{l}\text { DRŽAVA } \\
\text { Legislativa }\end{array}$ \\
\hline & $\begin{array}{l}\text { ZNANSTVENE INSTITUCIJE } \\
\text { akademije znanosti, instituti, sveučilišta }\end{array}$ \\
\hline MIKRORAZINA & $\begin{array}{l}\text { STRUČNA PRODUKCIJA } \\
\text { rječnici, savjetnici, gramatike, članci, knjige }\end{array}$ \\
\hline $\begin{array}{l}\text { KOMUNIKACIJA } \\
\text { stabilizacija i naturalizacija jezične norme u } \\
\text { prestižnim tipovima javnog diskursa }\end{array}$ \\
\hline
\end{tabular}

Tablica (Czerwiński 2009:14)

a) Makrorazina - jezična politika manjinskih zajednica definirana je prije svega Ustavom Republike Srbije (gdje se uopćeno navode prava manjinskih zajednica na uporabu jezika (vidi za detalje Ustav, član 75. član 79. i član 199.), a detaljnije Zakonom o nacionalnim savetima nacionalnih manjina ${ }^{9}$. $U$ tim se dokumentima sintagma ,jezik i pismo“ odnosi na jezik i pismo manjine, ali nigdje se izrijekom ne definira što je točno taj jezik niti se izrijekom spominje ime jezika za svaku posebnu manjinu. Tako da je definiranje „hrvatskoga jezika“ prepušteno predstavnicima hrvatske zajednice koji su u poziciji moći da o tomu odluče. U praksi sintagma „hrvatski jezik“ podrazumijeva „hrvatski standardni jezik“.

b) Mikrorazina - znanstvenih institucija s hrvatskim predznakom u Vojvodini nema, a njihov izostanak pokušava nadomjestiti Zavod za kulturu vojvođanskih Hrvata stručnom produkcijom pisanom uglavnom hrvatskim standardom. No, kako je u pitanju stručna tematika koja nema značajniju publiku, ne može se reći da ta produkcija ima utjecaja na upoznavanje ili promoviranje hrvatskoga standarda među manjinskom hrvatskom populacijom.

Kada je u pitanju komunikacija - jezik je svakodnevne komunikacije gotovo bez iznimke srpski. Pokušaji pojedinih predstavnika manjinske zajednice da se u službenim prilikama služe hrvatskim standardom zbog čestih neuspjeha češće imaju negativan utjecaj na prihvaćanje hrvatskoga standarda nego što potiču njegovu uporabu.

9 „Sl. glasnik RS“, br. 72/2009, 20/2014 - odluka US i 55/2014. 
Čak i kada je u pitanju nastava na hrvatskom jeziku (ovaj se rad referira na „cjelovitu“ nastavu - dakle onaj oblik nastave u kojem učenici pohađaju hrvatske razrede gdje u kojima kao materinski jezik uče hrvatski, a ostale predmete slušaju na hrvatskom standardu u onolikoj mjeri koliko predavač vlada njime (što nije čest slučaj) a koja postoji od 2002., ne možemo govoriti o uporabi hrvatskoga standarda kao sredstva komunikacije. ${ }^{10}$

Da se unatoč desetljeću nastave hrvatski standard nije uspio stabilizirati ni kao jezik prestiža među manjinom ni kao sredstvo svakodnevne komunikacije pokazuje ne samo iskustvo iz prakse ${ }^{11}$ nego i istraživanje koje je 2010 . proveo Vuković (Vuković 2010), ali i ono iz 2015. koje je radio Hodges. ${ }^{12}$ Kompleksnost pitanja hrvatskoga jezika u Vojvodini vidi se i iz popisa stanovništva iz 2002. godine prema kojemu u Vojvodini živi 56546 Hrvata, a samo su 21.053 osobe hrvatski navele kao materinski jezik. Osim toga, više od polovice učenika hrvatskih razreda smatra kako su hrvatski i srpski jezik jedan jezik (Vuković, 2010).

Za razliku od Hrvatske gdje je konsenzus govornika bio jak i jednoznačan, što Vuković objašnjava načinom na koji su se Hrvati oblikovali kao nacija i diskursna zajednica (Vuković 2010), Hrvati su u Vojvodini uslijed povijesnih promjena ostali izmješteni izvan granica Hrvatske te su bili na rubovima procesa uspostavljanja nacije. Osim toga velika prostorna disperzija Hrvata u Vojvodini te dijalekatska raznorodnost govora, kao i okruženost pripadnicima drugih etničkih skupina čiji je jezik malo ili nimalo razumljiv dovela je do toga da se u službenoj komunikaciji služe srpskim standardom (Vuković 2010). Kako je riječ o genetski srodnim jezicima među kojima nema prepreka u sporazumijevanju kao zbog izostanka upoznavanja narječja i dijalekata hrvatskoga jezika kroz školstvo, kod

10 Izostanak lektorata za hrvatski jezik ili nekog drugog visokoškolskog usavršavanja rezultira nedostatkom kadra za nastavu na hrvatskom jeziku. Tako u praksi (osim predmeta Hrvatski jezik koji predaju učitelji koje šalje MZOS) ostatak predmeta uglavnom predaju kolege koji su se školovali u Novom Sadu ili Beogradu, a „hrvatski jezik" se svodi na uporabu hrvatskog strukovnog nazivlja.

${ }^{11}$ Autorica je provela 4 godine radeći u MZOS-u kao učitelj i koordinator hrvatske nastave u Vojvodini.

12 Producing and contesting the national order of things: tracing how language standardisation processes and state effects configure (non)users near the Serbian/Croatian border. Istraživanje još nije objavljeno, a podaci kojima smo se služili s predavanja su koje je dr. Hodges održao 15. 12. 2015. godine gdje je prikazao rezultate istraživanja. 
većine izostaje svijest o tomu da lokalni govori („,̌̌okački“ ili „bunjevački“) pripadaju korpusu hrvatskoga jezika. ${ }^{13}$

\section{Zaključak}

Iz navedenih se primjera vidi tek dio kompleksnosti manjinskoga pitanja Hrvata u Vojvodini. S jedne su strane izloženi isključivim narativima predstavnika zajednice koji im propisuju prakse za očuvanje identiteta, dok upravo neke od tih praksi (upisivanje djece u hrvatske razrede) tu istu identifikaciju onemogućuju zbog neadekvatnih sadržaja mitske povijesti. Hrvatski standardni jezik koji su pokušali stabilizirati nema veću primjenu u svakodnevnim praksama. Značajan je samo na simboličkoj razini kao jedno od prava koje je manjina ostvarila, no njegovo ustaljivanje kao stvarno sredstvo komunikacije izostaje.

Kada govorimo o korelaciji etničkoga identiteta i stavova spram hrvatskoga standardnog jezika, zaključujemo da je hrvatski standard uvijek „tuđ“, odnosno „onako kako se kaže u Hrvatskoj", a ne „onako kako govorimo mi, Hrvati“. Lokalni hrvatski govori su (bili) (auto)označiteljem identiteta, ali nikada nisu bili u poziciji prestiža u odnosu na većinski, dominantni srpski jer su se povezivali s konceptima ruralnoga. Prestiž unutar manjinske zajednice nije uspio ostvariti ni hrvatski standard, osim u pisanim publikacijama.

\section{LITERATURA}

B. Anderson, Imagined Communities, Reflections on the Origin and Spread of nationalism, Verso, London - New York 1991.

Mario Bara i Aleksandar Vukić, „Konstruiranje identiteta na etničkoj periferiji - slučaj bačkih Bunjevaca.", Hrvati u Vojvodini: identitet(i), procesi $i$ društvene aktivnosti, 2012, 71-97.

W. L. Barsalou, "Situated simulation in the human conceptual system", Language and cognitive processes, 2003, 18 (5/6), 513-562.

${ }^{13}$ Pojam „standardni jezik“ razlikujemo od „jezika kao sustava“ (Silić, 1999) ne smatrajući pri tomu kako u takvoj odrednici potonji nije sustav (Kodrić, 2009: 84). Zako sintagmu "jezik kao sustav" ovdje donosimo u značenju hrvatski jezik u ukupnosti svih njegovih narječja, dijalekata i pripadajućih govora (i to prema podjeli kako ju donosi suvremena dijalektologija (Lisac 2003), a "hrvatski standardni jezik" sa svojim funkcionalnim stilovima predstavlja jedan (dogovoreni) oblik toga jezika sustava. Kada su u pitanju govori Hrvata Bunjevaca i Hrvata Šokaca u Vojvodini (inače govori štokavskoga narječja), smatramo da pripadaju hrvatskomu jeziku (Lisac 2003; Sekereš 1980). 
Maciej Czerwiński, „Jezik - izvor nacionalne i državne homogenizacije: Izabrani prilozi“, Jezični varijeteti i nacionalni identiteti, Prilozi proučavanju standardnih jezika utemeljenih na štokavštini, 2009.

Jasna Čapo, „Identitet je predodžba i projekcija budućnosti, a ne prošlosti“, Hrvati u Vojvodini: identitet(i), procesi i društvene aktivnosti 2012., 247-261.

J. Freedman i G. Combs, Narativna terapija, socijalna konstrukcija omiljenih stvarnosti, Psihopolis institut, Novi Sad 2009.

Andrew Hodges, (2016) Producing and contesting the national order of things: tracing how language standardisation processes and state effects configure (non)users near the Serbian/Croatian border (istraživanje; rad nastao na osnovi istraživanja, u pripremi)

D. Kahneman, Misliti brzo i sporo, Mozaik knjiga, Zagreb 2013.

G. Lakoff, The Political Mind A cognitive Scientist's Guide to Your Brain and It's Politics, Penguine Books, London 2009.

Josip Lisac, Hrvatska dijalektologija 1. Hrvatski dijalekti i govori štokavskog narječja i hrvatski govori torlačkog narječja, Golden marketingTehnička knjiga, Zagreb 2003.

Liisa H. Malkki, Purity and Exile: Violence, memory, and national cosmology among Hutu refugees in Tanzania, The University of Chicago Press, Chicago and London 1995.

Dan P. McAdamas, The Redmeptive Self Stories Americans Live By, Oxford University Press Oxford 2006.

Anita Peti-Stantić i Keith Langston, Hrvatsko jezično pitanje danas: identiteti $i$ ideologije, Srednja Europa, Zagreb 2013.

Stjepan Sekereš, „Govor u zapadnoj Bačkoj“, Zbornik za filologiju i lingvistiku XXIII/1, 1980.

M. Stanojević, Konceptualna metafora temeljni pojmovi, teorijski pristupi $i$ metode, Srednja Europa, Zagreb 2013.

Karpman Steven, Živeti bez igara, drmaski trougao u međuljudskim odnosima, Psihopolis institut, Novi Sad, 2015.

Dubravko Škiljan, Govor nacije : jezik, nacija, Hrvati, Golden marketing, Zagreb 2002.

Mark Turner, The Literary Mind, Oxford University Press, New York - Oxford 1996.

Petar Vuković, „Kako skrbiti za hrvatski jezik u Vojvodini“, Godišnjak za znanstvena istraživanja 2, 2010.,79-103.

Michael White, "Deconstruction in therapy", Dulwich Centre Newsletter 3, 1991., 21-40. 
Sue Wright, Jezična politika i jezično planiranje: od nacionalizma do globalizacije, Fakultet političkih znanosti, Zagreb 2010.

\section{Sažetak}

Priče su osnovno sredstvo putem kojeg konceptualiziramo svijet. Kroz narative koji su rezultat proživljenih iskustava interpretacije istih, stvaramo identitet. Osobni identitet je, tako, narativ, a osim osobnog identiteta i društvo konstruira narative. I u jednom i u drugom Isučaju jezik igra ključnu ulogu - istovremeno je i sredstvo konstrukcije narativa ali i može biti i markerom identiteta. Ovaj rad prikazuje nacionalni identitet kao konstrukt ilustrirajući vezu između jezika i nacionalnog identiteta među Hrvatima u Vojvodini. Također, prikazuje najčešće narative u hrvatskom manjinskom mediju i pokazuje kako se mitsko-povijesni sadržaj, kroz te narative, prezentira učenicima koji pohađaju nastavu na hrvatskom jeziku u Srbiji.

\section{Croatian language and naratives among Croats in Vojvodina}

\section{(Summary)}

Stories are one means through which we conceptualize the world. Through narratives we produce (as a result of experiences and the interpretation of those experiences) a personal identity. Personal identity is therefore a narrative, and in addition to this, society constructs narratives. In both processes language plays a key role it mediates the narrative whilst also acting as an identity marker. In this paper we will analyze national identity as a construct, illustrating the relations between language and national identity among Croats in Vojvodina. We will also analyze narratives in the minority media and show what mythico-historical content is presented to pupils in Croatian stream classes in schools in Vojvodina.

Key words: narrative, language, identity, Croats, Vojvodina 